\title{
LOCAL ECONOMIES, TRADE, AND GLOBAL SUSTAINABILITY
}

\author{
by Patricia E. Perkins \\ Associate Professor \\ Faculty of Environmental Studies \\ York University \\ North York, Ontario M3J 1P3
}

Tel: (416) 736-2100, ext. 22632

Fax: (416) 736-5679

E-mail: esperk@yorku.ca

\author{
Paper presented at the \\ VIth International Planning Environment Research Group Conference \\ on "Local Economic Restructuring: Social and Environmental Impacts"
}

\author{
27-30 June 1999 \\ Brunel University \\ London, UK
}

\begin{abstract}
Bioregional and "ecological economics" theory describes the growth of local economic linkages as vital to move post-industrial economies in the direction of sustainability. This involves expanding local stewardship over environmental and economic resources, so that progressively more production for local needs can be done within the community. Far from existing solely in the realm of theory, this is a pattern which is becoming more and more familiar in many parts of North America and Europe. The blossoming initiatives to create local, community-centred economies can be understood in light of the long history of environmental challenges faced by people living in the industrialized North, and the double economic blows of recession and trade liberalization/globalization exemplified by the passage of GATT and NAFTA and the development of the EC in the 1990s.

This paper discusses the dynamic relationship between globalization and local economic development in the North from both theoretical and practical viewpoints. It provides examples from Toronto, Canada of the synergy among environmental awareness, community organizing and "alternative" employment creation (e.g. in environmental remediation and energy conservation activities) which can accompany recession or trade-induced worker layoffs. The resulting local economic patterns tend to be "greener" and more socially sustainable than the globally-tied economic linkages they replace.
\end{abstract}




\section{LOCAL ECONOMIES, TRADE, AND GLOBAL SUSTAINABILITY}

\section{Introduction: Economics and "Local Economies"}

Economics as a discipline has traditionally been only peripherally concerned with the spatial distribution of economic activity.(1) Neoclassical economics' rise to preeminence has coincided with technological changes in transportation and communications which have facilitated the movement of money, goods and ideas; economists have regarded the actual location of production, distribution, and consumption in relation to each other over the face of the globe as something which the market can easily mediate efficiently and well.

The spatial distribution of economic activity is receiving new attention from economists, however. Phrases like "economies of proximity", "industrial ecology", and "agglomeration economies" are emerging in the literature, and some economists are attempting to come to terms with the limitations of market theory (or the need for its expansion) in explaining economic relationships "on the ground". Paul Krugman, for example, has developed new theoretical approaches to international trade which supplement "comparative advantage" by emphasizing historical patterns of industrial development as determinants of regional specialization (Krugman, 1990; Krugman, 1997). Institutional economists like Douglass North recognize social, political, regulatory and other factors as crucial to understanding the economic development of a region (North, 1989).

Economic globalization itself leads to at least two spatially-related conundrums: 1) the technologies vital for fast long-distance transportation of goods, "just-in-time" inventory control, and global corporate management depend largely on an accelerating use of fossil fuels and other minerals which arguably cannot continue indefinitely; and 2) global sourcing using the cheapest primary materials and labour inevitably leaves large amounts of (only marginally less attractive) labour and resource inputs unutilized. While this may not be a "waste" within the rationale of the individual corporation or industry, it imposes tremendous costs from the viewpoint of a community, region or nation (Sachs, 1993; Shiva, 1993; Altvater, 1993; Shuman, 1998).

"Local economics", or the analysis of economic processes from a relatively small-scale community/political economy perspective, addresses both of these conundrums. By focusing on the spatial relationships between production and consumption while emphasizing the importance of production process choices and what happens to wastes, "local economics" lays the groundwork for understanding what may become of economies if globalization indeed proves to be technologically, politically, and ecologically unsustainable. In the present, "local economics" also highlights and examines the situation of those workers and potentially useful primary inputs which are deemed superfluous or underutilised by the global market.

In principle, community-centred economic and social networks are advantageous on a number of fronts. They teach and foster democracy because local political decision-making happens in a 
decentralized way. The environmental effects of public decisions are clearly apparent to residents familiar with local ecological constraints, so decision-making tends to be "greener". It may also be easier at the local level to see benefits instead of drawbacks in social and ecological complexity and diversity. Short-distance trade and food networks are healthful, reduce climate change stemming from transport, create local jobs, keep money within communities, and can meet particular tastes and demands efficiently. People may be less resistant to taxation when they can see and benefit directly from the results of government spending. (2)

I am using the phrase "local economics" to mean the spatial relationships between production, consumption, inputs and waste products, in the context of a specific ecological, social, political and geographic environment. Whether or not production, consumption, inputs and wastes are measured and denominated in money terms, it is their "local-ness" which is crucial from this perspective; efficiencies in the use of labour and inputs are evaluated from the viewpoint of the whole local economy, not the regional, national, or international economy. The boundaries of the local economy thus need to be defined carefully -- what is meant by "local" will differ in each particular case. Territorial distinctions can be the source of potential conflicts where different groups of people have opposing spatial interests or claims. But in many places around the world, people have come to terms with and reached a collective understanding of the overlapping political jurisdictions, ecological or bioregional areas such as watersheds or geologically-distinct regions, and historically-derived land-use divisions, which together determine the area of a "local economy".

\section{Trade and Community}

The insidious effects of trade on human communities and on local economies have been documented and commented upon by a number of writers. Marcia Nozick, for example, points out that "diversity and uniqueness of place is lost in the process of economic globalization (the replacement of local markets with global markets). We forget who we are and where we come from... Rootlessness, transitoriness and dispossession are the fall-out of an increasing trend toward globalization and global competition... Many industries are viable within their local regions, yet they are being shut down because of global management" (Nozick, 1992, pp. 3-6). She lists five major "pressure points of community breakdown": economic de-industrialization, environmental degradation, loss of local control over communities, social degradation and neglect of basic human needs, and erosion of local identity and cultural diversity (Nozick, 1992, p. 7).

How does this process happen? "As a community is seduced into wanting the products of another region they will become dependent on those products and give up, often unknowingly, the control over their community. The economic surplus created within a community is then sent out of the community to buy the wanted goods. If the surplus were spent in the community it would be much more prosperous" ("Introduction to Bioregionalism", 1991, p. 4).

Herman Daly makes the similar observation that trade "sins against community by demanding 
more mobility and by further separating ownership and control" and that it "sins against distributive justice by widening the disparity between labour and capital in high wage countries,... against macroeconomic stability,... and also against the criterion of sustainable (economic) scale" (Daly, 1993, p. 129).

The Canadian Environmental Law Association, in a report on the environmental implications of NAFTA and other trade agreements which it prepared for the Ontario Ministry of Environment and Energy, documents some of the negative environmental impacts of trade liberalization and provides evidence from Canadian experience (CELA, 1993). Among other things, agreements like NAFTA can undermine local and provincial environmental standards, create political pressure for non-enforcement of environmental regulations, speed and exacerbate the depletion of natural resources, and shift the policy debate in anti-community and anti-democratic ways (Nader et.al., 1993; Hines, 2000).

Admittedly, there are good reasons for some amount of trade. The dissemination of "ideas, knowledge, art, hospitality, travel" -- to use the words of John Maynard Keynes -- enriches people's lives in countless ways (Moggeridge, 1993). Medical devices and drugs produced in some places should be supplied for humanitarian reasons to those who need them worldwide. Foodstuffs may need to be traded in time of famine, and exchanges of minor food and craft items satisfy people's attraction to the unusual and new. As a contribution to diversity -- which is an essential part of many definitions of sustainability - such limited trade could be a positive factor (Daly, 1993, pp. 1-2).

Nonetheless, it seems to be trade's propensity to grow, and feed on itself and keep growing, that is its most dangerous characteristic -- both for human communities and for the environment (Ponting, 1991, p. 154). Trade activates and stimulates a number of "positive feedback" mechanisms which help its scale to keep increasing. For example, a corporation which avoids paying for pollution-control equipment may reap higher profits, which allow it to buy out another firm and "rationalize production", putting some people out of work, which forces them to move away and saps consumer expenditures, which undermines the stability of the community and reduces local political pressure for pollution control. The firm can then threaten to lay off still more workers if the community does not make land-use, tax or other concessions. Its profits rise further; it buys other plants in nearby towns. To benefit from economies of scale, it reorganizes its plants to specialize, each producing one component part so that none of the plants makes anything that is useful without information held by the firm's central management. Production decisions which are vital to the health of all the communities where plants are located are made in a far-away headquarters office, and so on. The expansion of such processes on a global scale is possible and economically feasible only because of trade.

In nature, cycles often depend on "negative feedbacks", not positive ones. There are many natural processes which contain the seeds of their own limitation. For example, the growth of individual plants and animals is limited, once they have reached adulthood, through species-specific hormonal and chemical processes which have apparently evolved to help the species survive within the constraints of its ecosystem. These processes work like a thermostat designed to turn the heat on when the temperature drops below a certain level; if the temperature 
rises too far, the thermostat turns the heat off again. A "negative feedback" corrects any departure of a system from normalcy (Peet, 1992, pp. 75-76).

What sorts of "negative feedbacks" might we envision which would help to keep trade in check? Some recent writings on trade and environment stress the importance of protectionism, or controls on trade imposed at the level of national governments, to accomplish the goal of limiting its scale. Herman Daly and John Cobb, for example, write that a sort of targeted protectionism is needed to foster economic self-sufficiency within the United States (Daly and Cobb, 1989, p. 363). Stronger international environmental agreements in conjunction with revised trade agreements are also cited as a way of reorienting trade for sustainability (Lang and Hines, 1993, pp. 138-140). Others advocate limits or taxes on international financial transfers, to reduce the facility with which global corporate transactions are made (Altvater, 1993, pp. 259-260; Tobin, 1995). This regulatory approach to limiting trade, motivated in part by social and ecological concerns, is one way in which human society may be able, as Elmar Altvater says, to "build into the functioning of the economic system a series of imperatives which prevent ecological damage" (Altvater, 1993, p. 213).

What I would like to outline below is another approach which -- while not at all contradictory to national and international regulation of the global market -- instead places its primary emphasis at the local, community level.

\section{Self-limiting Trade: Theory}

What are some of the analytical foundations of a community-centred approach to "negative feedbacks" for trade? For one thing, they require theoretical tools which are far more adept than those of traditional economics. Neoclassical economics, based on analysis of self-interested individuals' behaviour, ignores other entire realms of human action and motivations - such as the fact that people often make choices with the welfare and interests of others in mind (Nelson and Ferber, 1993; Folbre, 2001; Van Staveren, 2001).

While the theoretical economic justifications for trade's supposed contributions to economic efficiency are increasingly recognized as faulty (Krugman, 1990; Daly and Cobb, 1989; Ropke, 1993), traditional economic analysis is still used at all levels of policy decision-making to justify government action (and inaction), from international trade agreements to child care programs (Waring, 1988). Its failure to measure many economic contributions made by women, its emphasis on individual over collective wants/needs, and the translation of this emphasis into policy, harm communities in both the South and the North (Elson, 1993; Palmer, 1992; Nozick, 1999).

New economic theories and models, based on collective processes and the centrality of people's homes and communities to their ways of life, are beginning to appear. Hilkka Pietila, for instance, envisions economic transactions as taking place within a series of three concentric circles. The central one is the "free" economy, consisting mainly of homes and family groups, in which labour and goods are exchanged for free; surrounding this is the "fettered" economy, 
where governments regulate and control markets to which different people have varying degrees of access; finally, surrounding the others, there is the "closed" economy, to which individuals have little access because international transactions are organized almost entirely by transnational corporations and government treaties (Pietila, 1997).

Brian Milani calls for reframing of the state "as a means to help the individual to fulfill a social purpose rather than as a policeman or as a substitute for real social bonds". He speaks of "community oriented self-regulation" as a process which could "design social forms to consciously cultivate and support that positive side of the human personality that seeks harmony, growth and meaning" (Milani, 2000, p. 184).

Mark Roseland analyses the synergies between "natural capital" and "social capital" in generating sustainable community development. He says, "the critical resource for enhancing social capital is not money - rather, the critical resources are trust, imagination, the relations between individuals and groups, and time... Focusing solely on money to provide security is using nineteenth-century thinking to address twenty-first-century challenges" (Roseland, 1999, pp. 198-204).

Much theoretical work which is central to feminism is also vitally important for community-based approaches to issues of international significance (including trade). Marcia Nozick summarizes these contributions as "...a raising of consciousness to appreciate feminine, life-affirming values, long neglected by Western culture. They are values similar to those held by aboriginal cultures and the ecology movement. They include:

-- Co-operation, empathy and nurture stemming from a relational, nonhierarchical view of the world;

-- $\quad$ A focus on process rather than end results: ends and means are one;

-- $\quad$ A belief that social change begins with personal transformation;

-- $\quad$ The valuing of intuition, subjectivity, creativity and spontaneity” (Nozick, 1992, p. 38).

These feminine principles are forming the foundation for an alternative, "feminist ecological economics" vision of society. It relates to how we work, organize and make decisions -smaller, more personal structures and processes, co-operative work situations, consensus decision making and reliance on community supports and the informal economy. They are values which support the building of sustainable communities.

The central theoretical insight linking community-based processes with "negative feedbacks" on trade is that just as trade can work to destroy community, strong communities have the potential to limit the growth and extension of trade. The terrain of the local is extremely important, not just because it is "close to home", but also because community-based economic alternatives and resistance to centralized economic control represent a fundamental challenge to the juggernaut of globalization (Korten, 1994). 
Vandana Shiva puts the issue this way: "What at present exists as the global is not the democratic distillation of all local and national concerns worldwide, but the imposition of a narrow group of interests from a handful of nations on a world scale... The roots of the ecological crisis at the institutional level lie in the alienation of the rights of local communities to actively participate in environmental decisions. The reversal of ecological decline involves strengthening local rights. Every local community equipped with rights and obligations, constitutes a new global order for environmental care" (Shiva, 1993, pp. 154-155).

For Barbara Brandt, stronger community-based economies not only help people to survive the vicissitudes of world market fluctuations, they hold the seed of more fundamental economic transformation. "As individuals and households become more self-reliant and empowered, they lay the groundwork for new community responses to larger social and economic problems. When plant closings, layoffs, loss of local stores, or other large-scale economic hardships afflict their communities, such empowered, creative individuals may be more able to develop new solutions to these problems. And the new community ties they have been forming through their shared activities serve as a base for building new economic structures and enterprises that more fully meet their community's needs" (Brandt, 1995, p. 153).

Strong communities act as "negative feedback" mechanisms on trade in two main ways:

-- $\quad$ Through community solidarity, knowledge of the local ecosystems, and a sense of common purpose, they are able to stand up to intimidation by large corporations, resisting production practices which endanger workers, social solidarity, or the local environment (Lipschutz, 1999). This effectively limits corporate control over the geographical areas, natural resources, and labour power involved. The more distant the corporation's headquarters and the less community-sensitive its production practices, the more intensely these will be resisted by a strong community. (3)

-- $\quad$ As globalization increasingly strips control over production and consumption from communities, consigning many of them to stagnation when cheaper sources of resources or labour power are found elsewhere, they lose wages and disposable income. If they are able, because of strong community ties, to begin producing locally for local needs, they may be able to effectively remove themselves from the global trading system, at least in part. If its participation is not needed by the global economy on the production side, a strong community can bid permanent farewell to the consumption side as well (and still meet its inhabitants' needs), thus shrinking the size of the globalized economy.(4)

An emphasis on strengthening community, therefore, holds the possibility not just of limiting trade through centralized administrative and regulatory means (which, besides being hierarchical, are subject to the vagaries and influences of the political process), but of planting within the global trading system a size-limitation mechanism which becomes more effective the larger the trading system grows. 
IV. Self-Limiting Trade: Practice

Communities which can meet their own needs are less dependent on the global economy. The rapid growth of the "service sector" in relation to the overall economy implies that an increasing localization of production, at least in money terms, is well advanced in many parts of the world (Krugman, 1997, pp. 211-212). But a local economy requires goods as well as services, so the crux of local economic sustainability is the extent to which basic inputs to the economy are generated locally - beginning with food, clothing, shelter, and the raw materials for other locally-consumed products.

In self-sufficient communities, it is possible to live a healthy, fulfilling, productive life without consuming goods and services which come from far away. But this requires knowing one's neighbours: their skills, needs, abilities, and trustworthiness. This makes possible the sorts of exchanges which are efficient and beneficial for everyone concerned -- through skills exchanges, community-supported agriculture, Local Enterprise Trading Systems, credit unions or informal credit groups, urban gardens, child-care and other cooperatives, environmental housing improvement programs or any other enterprises where local resources are transformed into goods and services which local people need (Norberg-Hodge, 1994, pp. 3-4; Shuman, 1998; Milani, 2000; Pierce and Dale, 1999).

Working to create community has a lot to be said for it. It's environmentally and economically sensible to reduce the transport of things from where they naturally occur or are produced to where they are used and enjoyed. This requires less fuel, involves less spoilage and breakage along the way, implies less risk and dependence on global financial and transportation networks, and makes possible a closer match between what people want and what they get. The costs of international transfers of goods seem likely to rise, not just because of declining stocks of fossil fuels and pollution regulations related to climate change, but also because of the risks and complexity of international distribution systems. This may make locally-produced goods more and more competitive in the coming years. Moreover, community work is often fun and rewarding in an inter-personal sense, and it leads to the development of the social ties and friendships which make life more complex and rewarding and constitute the foundations of a social culture.

Building local economic self-sufficiency involves fostering the development, preservation, and appreciation of the skills needed to maintain high quality of life. The transition to a more sustainable future involving much less trade than at present, between much stronger and more self-sufficient local communities, offers many challenges. People all over the world are already working to address these challenges by building and strengthening local, community-based economies.

The Community Indicators movement, which includes initiatives in hundreds of towns and cities, involves local people in developing benchmarks for their community's improvements in quality of life, measuring such things as economic security, ecological integrity, and political empowerment. Sustainable Seattle, for example, beginning in 1980, has monitored more than 100 indicators in the Seattle metropolitan region. Citizens in Jacksonville, Florida have used 
their local indicator system to rate politicians and public expenditures and to press for environmental clean-ups (Shuman, 1998:185). A few communities, including Oakland, California and Chester, Pennsylvania, have developed methodologies for measuring imports to and exports from their local economies, and thus keeping track of leakages which damage community economic sustainability and moving toward import substitution. The Community Renewal Project at the Rocky Mountain Institute in Colorado uses this type of analysis in its local economic development work (Shuman, 1998:186). GPI Atlantic, based in Halifax, Nova Scotia, is developing similar community sustainability indicators for the Maritimes in Canada.

Models for local economies vary widely. From the co-operative based economies of Prince Edward Island and Mondragon in Spain to the ecological agriculture based economy in Gaivotas, Colombia; from the local lending-circles of the Grameen Bank in Bangladesh, and similar microfinance enterprises throughout Asia, Africa, and Latin America to the Local Currency movement in Europe, North America, Australia and New Zealand (Raddon, 2002), local economy initiatives are as diverse as the populations that invent and build them.

\section{Toronto's Local Economy}

Toronto, for example, is home to a vast and growing network of locally-based initiatives aimed at creating jobs by addressing environmental problems, and increasing local control of basic economic necessities: food, shelter, transportation, money.

When Central American refugees form an agricultural cooperative, lease land outside Toronto, and provide weekly food baskets of organic vegetables to urban consumers in a "community shared agriculture" project; or when the City of Toronto provides seed loans for energy-efficient retrofits of private housing which create construction jobs and save both energy and money; or when a largely abandoned industrial area along the Lake Ontario waterfront is converted to a "green industry" centre, this contributes to the development of a more ecological, less wasteful, more locally-centred economy.

There are countless more examples in Toronto of small-scale organizing and local economic initiatives involving people of all ethnicities and backgrounds, some of which are summarized in Box 1.

\section{Box 1: Local Economy Initiatives in Toronto}

- $\quad$ The Toronto Renewable Energy Co-operative (TREC) is constructing large windmills on the shores of Lake Ontario to produce electricity for the city's power grid, lowering the utility bills of co-op members (TREC, 2001). 
-- $\quad$ Ethiopian immigrants, many of them taxi drivers, create loan pools like those they knew in Africa, giving members of the group access to far more credit than commercial banks would provide.

-- Neighbourhood activists in the South Riverdale neighbourhood and other areas of the city work with government and industry representatives to carry out environmental clean-ups, meet the challenges posed by plant closings/"restructuring", and plan for healthy neighbourhood development.

-- $\quad$ Foodshare, a local nonprofit organization, fosters community gardens, rooftop gardens, and organic food production and consumption through its "Good Food Box" programs, which provide delivery of local produce direct to households (Foodshare, 2001).

-- $\quad$ The Toronto Food Policy Council works to increase understanding and feasibility of locally-based food networks.

-- $\quad$ The Toronto Island Community Land Trust, negotiated by local residents, shows how complex land ownership and stewardship issues can be resolved using unconventional institutional approaches.

-- $\quad$ Pioneering eco-technology pilot projects include the Toronto Board of Education's Boyne River Ecology School and Toronto Islands Natural Science School, and the privately-built, award-winning Healthy House, both autonomous "off-the-energy-grid" buildings featuring "living machine" natural wastewater treatment.

-- $\quad$ Green\$aver, established in 1993, performs home energy audits, repairs and retrofits, generating about $\$ 1.3$ million in the local economy over the past two years and forging wide-ranging partnerships to create jobs by upgrading the energy efficiency and environmental quality of buildings and of neighbourhood life (Green\$aver, 2001).

-- $\quad$ The Environmental Centre for New Canadians organizes recent immigrants to Canada around environmental issues, providing a focus for advocacy and job creation.

While some of these initiatives have received limited government assistance, others have had to fight restrictive government regulations and policies every step of the way. The lakeshore windmill project, for example, has faced a stringent Environmental Impact assessment on its siting, including allegations that migrating birds and Monarch butterflies will be harmed by the turbines; the many environmental benefits of producing electricity from wind power instead of fossil or nuclear fuels hardly fit into the standard land-use focused environmental impact 
procedures. At the same time, the project has benefited from policies of the provincial crown corporation Ontario Hydro which allow consumers' electric meters to run backwards if they are generating power for the grid, and from the municipal government's willingness to lease a site on publicly-owned land for the windmills. Plans for the Healthy House were sponsored by the federal Canadian Mortgage and Housing Corporation (CMHC), and the Toronto school board's commitment to environmental education led to the ecological pilot projects at the Boyne River School. But government policies wreaked havoc with citizens' initiatives for land management on the Toronto Islands until the City of Toronto was able to broker a deal resulting in the Community Land Trust.

On balance, it is the commitment, involvement and energy of non-governmental organizations, activists and individuals which seems decisive in the originality and success of such sustainable community-building initiatives.(5)

As the largest city in Canada, Toronto benefits from ethnic and cultural diversity and a wide range of community traditions, many of which have been part of the city's heritage for decades/generations even if they have their original roots in other parts of the world. Toronto also has relatively well-developed environmental and community organizations, and well-defined downtown urban neighbourhoods, which facilitate local-level organizing around particular communities' needs within the metropolitan area. At the same time, pressing urban environmental problems and an unemployment rate of well over 10 percent have put attention to local environmental and job creation issues at the top of the public agenda. This mix of diverse potentialities and needs characterizes many urban areas in Europe, North America, Australia and also throughout the South. They speak to the need to understand self-sufficiency and local-ness in this context in an outward-looking, tolerant way which is welcoming of diversity - far from the xenophobic or "survivalist" perspective on local sovereignty which suppresses divergence and dissent.

\section{The Potential of Local Economies}

The fact that examples of burgeoning local economies similar to Toronto's can be found all over the world indicates that in many different contexts, the potential is growing for economies to become less dependent on the global economy even as they continue to participate in it. In many places, including Canada today, the growth of local economies is also related to the cuts in government expenditures and fiscal restraint which are part of "structural adjustment"- whether mediated by the World Bank/International Monetary Fund, or part of a neo-conservative fiscal agenda. Communities worldwide are having their resilience tested as they struggle to find the means to meet people's basic needs.

This raises a number of interesting theoretical and empirical research questions, especially concerning the relationship between globalization and the growth of local economies (Perkins, 1996; Perkins, 2000). For example, is a focus on local economies misguided, short-sighted, or even elitist, because it takes attention away from many pressing and dangerous problems of globalization, especially the need for international income redistribution? What is the true potential of local economies to supply large quantities of basic necessities and consumer goods 
in an efficient and fair way, and thus to serve as a real alternative to the global market? Will local economies continue to be able to survive and grow "in the interstices" of larger-scale economic activity - and is this enough? Should progressive governments adopt policies which support and help to incubate local economic institutions and processes, or focus elsewhere and leave them alone? Or is removal of existing policy barriers to innovation and creative local-economy experimentation the most important priority?

Recognizing these crucial contextual questions, I would like simply to focus here on the potential for local economy creation in specific situations. While a local economy perspective is generally attractive from both a social and an environmental standpoint, building local economies seems easier in some circumstances than others. The following comments about the growth of local economies seem salient across a relatively wide range of circumstances.

During economic recessions, it is likely that more people will need the sorts of alternative sources of income that LETS systems and other local economy/community development initiatives can provide; they also will have more time for political organizing and volunteer work than in boom times when unemployment rates are lower. Retrofits and alternative uses of urban buildings (e.g. for food production and social services instead of industry) are probably more likely during economic recessions than booms. In Toronto, vacant industrial buildings downtown became available for urban food production, bicycle repair operations, community kitchens and other local uses during the recession of the 1990s; once the economy improved, such buildings began to be renovated into high-priced housing condominiums.

If environmental pollution becomes worse during boom times, however, this may lead to more public commitment and available funds for environmental organizing, job-creation in environmental remediation and other pollution-control work, and local political organizing around environmental causes.

The "push" factors for local economic development may thus fluctuate between an emphasis on local goods and service provision (during recessions) and environmental remediation/ protecting the local environment (during booms).

Government and private foundation-funded pilot projects serve as extremely useful examples of what local people can do, and their worth in demonstrating and fine-tuning the techniques of alternative energy, food and other local economic endeavours is crucial. The CMHC's sponsorship of the Healthy House, the City of Toronto's policy work on sustainable transportation and the Food Policy Research Council as well as Green\$aver, the school board's development of the Boyne River and Toronto Islands ecology school projects, are all examples of the important role of publicly-funded pilot projects.

Long-term demand and consumption shifts are inexorable; people's preferences are shifting toward greener products, more locally-produced food, reuse and recycling, etc. Local Agenda 21 initiatives play a role in this, as do consumer education, boycotts, and local entrepreneurial activities. Both the local-production and the environmental-protection sides of community-based economies are likely to be stimulated by these long-term trends. 
Changing, open, diverse societies clearly make the growth of local economies easier. Acceptance of loan pools as an alternative to banking institutions; shifts and widening of food tastes; international skills transmission; improvement in international income distribution as immigrants send money back home; all demonstrate the benefits and value of social diversity.

Pressures for more growth, trade, sprawl and globalization are intense, and the risks are growing of a cascading political/economic/environmental collapse. This means that the stakes are high and the need for local economic alternatives may suddenly become acute.

From a geologic time-scale perspective, economic change is quite rapid; possibly the theoretical studies and practical pilot projects of the kind discussed here will help to bring about an evolutionary shift toward more local economies "in time", even if the progress is hard to discern initially.

Just as social and ecological conditions differ from place to place, the pillars of each local economy will differ as well, and so will the priorities and patterns of each local economy's development.

\section{Conclusion}

As local economies grow in response to economic globalization and global ecological realities, their characteristics and implications will become clearer. Whether they represent an accommodation to the global economy or an alternative to it, local economies seem destined to play an important role in many people's lives.

There are at least two good reasons for economists, planners and policy-makers to pay attention to the growth of local economies: they can provide a socially and ecologically attractive alternative to globalization, and their growth seems to be at least partly driven by globalization -in other words, local economies are an emergent phenomenon worthy of attention in their own right.

What facilitates the growth of a local economy? Are there preconditions or requirements for its development? How does public policy affect this?

I believe it is easier for local economies to grow when all people have access to a guaranteed basic income, health care, child care and educational opportunities. This allows people, even if they lose or cannot get paid employment, to devote themselves to alternative forms of economic activity with a "safety net" in case of illness or change in life circumstances.

Flexibility in the way basic social services are provided is helpful because it allows people to switch to locally-sourced food, health care and housing if they wish, and use the money they may save for other things. This implies welfare payments of a "guaranteed annual income" kind, rather than food stamps, government housing, etc. 
Large-scale economic change happening suddenly in a local area is more conducive to development of local economic activity than protracted, smaller shifts. This is because in the former situation, people are less likely to feel personally responsible for their being laid off. When big changes hit a community, a unified response seems easier and new institutions and lifestyles are more acceptable.

If pilot projects or small-scale local economic endeavours pre-exist a globalization shock, this can help people to see them as a viable solution to new problems. There may be an openness to community approaches within a short time following economic upheaval which dissipates over time as people "adjust" on their own, so a strong energy for creation of community-based economic institutions may be lost in the initial learning-by-doing phase. Pre-existing trials and "fringe" projects can reduce this. Individual adjustment and alienation are dangerous because of the high costs in depression, family violence, alcoholism and other health effects, etc. This of course has many gender implications.

A strong community is essential! People who know each other well, and maintain intergenerational connections, strong local institutions like churches, parents' groups, clubs, and sports leagues, can create the fora for people to expand and develop their interpersonal ties into new areas. There is no substitute for this sort of community interpersonal self-knowledge.

The longer most people have lived in the area, the easier it is for a local economy to develop. People need to know each other as individuals, including each others' non-work related skills and strengths and needs. They need to know how the community works -- its institutions and history. And they need to know the local geographical area well: What grows in gardens? Where can you get sand, or walnut planks, or locally-grown apples?

The transition to more locally-centred economies may not at all be an easy one. Very often the market does not give clear signals of an impending economc or ecological crash. The price of cod, for example, did not rise to reflect the growing crisis before the collapse of the Northern Atlantic fishery. Because of global competitive pressures, the growing scarcity of many raw materials is not being reflected in price levels. So, while it is true that economic pressures may force communities to make some progressive changes, in many cases crises can just increase desperation, panic and competition. Although it is the responsibility of governments to foresee and forestall such crises, the widespread public lack of confidence in governments' ability to do so seems understandable and justified. However, I believe it is also true that public processes, and public money, can at times provide very useful support for grassroots economic initiatives.

Van der Ryn and Cowan (1996) mention a number of principles which can be applied to the policy formulation process in a sort of test of the degree to which it can be expected to produce ecologically-desirable outcomes. I have paraphrased these principles as follows:

-- $\quad$ Does it cross traditional disciplinary and jurisdictional boundaries?

-- $\quad$ Is it locally-specific, taking into account local social and ecological conditions? 
-- $\quad$ Does it include means to remediate past mistakes?

-- Does it encourage public questioning, learning and participation?

-- $\quad$ Is it concerned with conservation, regeneration and stewardship?

-- $\quad$ Does it allow for scale-mixing -- replication of the processes envisioned at both smaller and larger scales, as needed, to echo the fractal structure found in natural processes?

-- Do the geographic boundaries involved reflect geographic boundaries (watersheds, airsheds, soil distributions, etc.)?

Clearly, these questions imply a standard for policy-making which few, if any, governments anywhere in the world can now live up to! But they are, at the very least, forward-looking, and indicative of the kinds of changes which may be needed if the "state" -- local, regional, national and international -- is to take a leadership role in making ecologically-sensitive policy decisions. This includes decisions which can help locally-centred economies to grow and flourish.

The skeptical viewpoint on the role of public policy in fostering or even permitting local alternatives to globalization is strongly expressed by Gould, Schnaiberg and Weinberg (1996). They state: "Local citizen-worker environmental movements face considerable resistance from economc and political actors in their locality and their region.... Each of our empirical studies forces us to challenge the efficacy of 'think globally, act locally.' The central reason that acting locally is not sufficient to protect local ecosystems is that most environmental degradation is an outcome of the operations of the treadmill of production... (where) economic and political influence are linked." (Gould, Schnaiberg and Weinberg, 1996:164-173). They also question the potential of locally-centred economies to effectively counter globalization, stating: "We believe that while local movements can support a return to more personal, labor-intensive organizations, they cannot create the conditions necessary to sustain such economic reforms... In many ways, they yearn to reestablish community-based economic, social, and political organizations that sustain both the social and environmental bases of their personal and community lives. And yet we have noted that they generally lack the political power to confront the treadmill." (1996:199). They argue for extra-local coalitions of locally-based movements which can amass enough political power to challenge aspects of the global economic system.

Even fairly mainstream policy analysts call for increased democratization at the local level as a way to bring about "sustainability" -- although they tend to be somewhat unclear on what kind of sustainability they are talking about. For example, according to Churchill and Worthington, "An informed and active citizenry at the local level is the cornerstone of a viable civic realm in a global society. The consequences of globalization are comprehensible and concrete in the locality, and the potential for citizen-driven politics is greatest there. The central requirement for transition to sustainability is therefore widening the scope for meaningful and effective participation in policy and planning which links the locality to global forces." (Churchill and Worthington, 1995:101). 
Many authors emphasize the importance of change from the grassroots, beginning at the local level, if production processes are to become more ecological and globalization is to be confronted. Their emphases vary, but many give specific examples of how this process has already begun.

Helena Norberg-Hodge mentions local skills exchanges, community-supported agriculture, Local Enterprise Trading Systems (LETS), credit unions and informal credit groups, urban gardens, child-care and other cooperatives, environmental housing improvement programs, and other types of enterprises where local resources are transformed into goods and services which local people need (Norberg-Hodge, 1994:3-4).

For Roy Morrison, the steps involved in building an ecological democracy include democratizing finance (through credit unions and community-based banks), building community economies and especially local cooperatives for production and distribution, instituting new ways of accounting for and valuing environmental goods and services, creating a social wage which would provide some income for all, pursuing disarmament and demilitarization, developing an industrial ecology, dematerializing production, and developing a solar economy (Morrison, 1995:189-228). For Enrique Leff, the technological, economic and cultural changes which must take place will begin at the local community level, fueled by social struggle over access to resources and land. He sees this struggle as necessary if capitalism is to continue in a more ecologically sustainable form. (Leff, 1995:125-129).

As mentioned above, Toronto has ongoing experience with many of the initiatives which have become recognized as indicative that a locally-based economy is under construction.

Since by definition local economies are particular to specific local areas, they can best be studied in conjunction with activists and community groups in the places where they are emerging. To expand our view of local economies, thus, what is called for is more empirical economics -- from the grassroots.

In this paper, I have discussed the definition and characteristics of local economies, and suggested some criteria for public policy which might support or encourage the development of local economic initiatives. While examples do exist, both in Toronto and in other places, of publicly-funded pilot projects as well as longstanding and self-sufficient local-economy programs, it is important not to overstate the potential of public policy in this area. There is no substitute for the creativity and hard work of people -- usually volunteers -- striving in their own communities to build better and more ecologically sustainable local economies. 


\section{NOTES}

(1) Some examples of the types of spatial interests addressed in the economics literature include the location of industries in relation to markets, market size and economies of scale, natural resource endowments and specialization in international trade, and firms' location decisions in relation to raw materials and other production inputs. However, such important issues as the overall spatial relationships between raw materials, production plants, consumers, and waste disposal/recycling facilities are seldom addressed.

(2) The theory and practice of community-centred social and economic networks are discussed by a growing number of authors: Boswell, 1990; Forsey, 1993; Dobson 1993; Lappe and DuBois, 1994; Morrison, 1995; Norgaard, 1994; Nozick, 1992; Roseland, 1997; Shuman, 1998; Pierce and Dale, 1999; Hofrichter, 2000; Cox, 1997; Bernard and Young, 1997; Hines, 2000; Hannum, 1997; Beatley, 2000; Barker, 1999; Carrel, 2001;

(3) This has happened, for example, in a number of cases in North America and elsewhere involving mines which were opposed by local people on environmental grounds. Opposition led by aboriginal groups blocked development of the Windy Craggy copper and gold mine in northern British Columbia in 1993, and the Voisey's Bay nickel mine in Labrador in the late 1990s. Mine developments near Yellowstone Park in Montana, and in northern Wisconsin, were also halted by local environmentalists and native people in the late 1990s (Gedicks, 2000). In the South, coalitions of indigenous people and environmentalists were able to stop a Scott Paper Co. eucalyptus plantation in West Papua in 1989, a Conoco Oil expansion in Ecuador in 1991, and a Stone Container Co. lease and harvest of pine forests in Honduras in 1992 (Weissman, 1993), among many others. Asian auto companies' proclivity for locating new factories in non-union states of the Deep South in the U.S., instead of Midwestern communities where workers have experience in organized auto sector employment, is another example.

(4) This is related to the "second crisis of capitalism" argument advanced by James O'Connor (M. O'Connor, 1994). Workers at the former National Steel plant in the small town of Weirton, West Virginia banded together to buy the factory when the company was going to shut it down; Weirton Steel is now the second-largest majority worker-owned manufacturer in the U.S. The firm invests seriously in retooling and worker training for participation and responsibility in the company's decision-making (Lappé and DuBois, 1994:93). Similarly, workers at a paper mill in Kapuskasing, Ontario bought the plant from a multinational firm to protect their jobs when the plant was threatened with closure. The mining town of Kirkland Lake in northern Ontario decided to redevelop and market itself as a retirement community, creating many jobs, when its main employer, a mine, closed down. In Pittsburgh, Pennsylvania, the Steel Valley Authority helps workers laid off due to extensive industrial relocation and factory closures to create new local jobs in such enterprises as bakeries (Lappé and DuBois, 1994: 95-97). Organic farmers in Ireland - as in many other places -- have developed a growing local market for their produce in farmers' markets and restaurants, creating dozens of jobs (McMahon, 2001). A strong network of co-operatives in Evangeline and other areas of Prince Edward Island, Canada has enabled many communities in that long-isolated province to create an economy based on local 
agriculture, industry, and service provision for local needs (Roseland, 1998:164). When the town of Pattonsburg, Missouri was nearly destroyed by a flood in 1993, its citizens took the opportunity to move the town to higher ground and design a new community incorporating principles of ecological sustainability, including passive solar building construction, attraction of environmentally-responsible industries, biotreatment of municipal wastes in a wetland, and methane recovery from agricultural wastes for energy production (Sitarz, 1998:256).

(5) Sources on "green community development" in Toronto include: Roberts and Brandum, 1995; Community Economics (130 Spadina Avenue, Suite 402, Toronto M5V 2L4; Toronto Community Ventures News (158 Eastern Avenue, Toronto M5A 4C4). 


\section{REFERENCES}

Altvater, Elmar. 1993. The Future of the Market. London/New York: Verso.

Barker, Jonathan. 1999. Street-Level Democracy: Political Settings at the Margins of Global Power. Toronto: Between the Lines.

Beatley, Timothy. 2000. Green Urbanism: Learning from European Cities. Washington, DC: Island Press.

Bernard, Ted and Jora Young. 1997. The Ecology of Hope: Communities Collaborate for Sustainability. Gabriola Island, BC: New Society Publishers.

Boswell, Jonathan. 1990. Community and the Economy. London/New York: Routledge.

Brandt, Barbara. 1995. Whole Life Economics: Revaluing Daily Life. Philadelphia, PA / Gabriola Island, BC: New Society Publishers.

Canadian Environmental Law Association. 1993. The Environmental Implications of Trade Agreements. Toronto: Queen's Printer for Ontario.

Carrel, André. 2001. Citizen's Hall: Making Local Democracy Work. Toronto: Between the Lines.

Churchill, Derek and Richard Worthington. 1995. "The North American Free Trade Agreement and the Environment: Economic Growth Versus Democratic Politics." In Frank Fischer and Michael Black, Greening Environmental Policy: The Politics of a Sustainable Future. New York: St. Martin's Press.

Cox, Kevin R. 1997. Spaces of Globalization: Reasserting the Power of the Local. New York/London: Guilford Press.

Dale, Ann. 1993. “A Charter for the Environment," Sustainable Development Research Institute Newsletter. University of British Columbia, vol. 1 issue 3, pp. 1-2.

Daly, Herman E. and John Cobb Jr. 1989. For the Common Good: Redirecting the Economy Toward Community, the Environment, and a Sustainable Future. Boston: Beacon Press.

Daly, Herman. 1993. "From Adjustment to Sustainable Development: The Obstacle of Free Trade", in Ralph Nader et.al. (eds.), The Case Against Free Trade: GATT, NAFTA, and the Globalization of Corporate Power. San Francisco/Berkeley: Earth Island Press/North Atlantic Books.

Dobson, Ross V.G. 1993. Bringing the Economy Home From the Market. Montreal: Black 
Rose Books.

Elson, Diane. 1993. "Gender-Aware Analysis and Development Economics," Journal of International Development, vol. 5, no. 2.

Folbre, Nancy. 2001. The Invisible Heart: Economics and Family Values. New York: The New Press.

Foodshare. 2001. Website: http://www.foodshare.net/.

Forsey, Helen. 1993. Circles of Strength: Community Alternatives to Alienation. Philadelphia, PA/Gabriola Island, BC: New Society Publishers.

Gedicks, Al. 2000. "Silencing the Voice of the People: How Mining Companies Subvert Local Opposition." In Richard Hofrichter (ed.), Reclaiming the Environmental Debate. Cambridge, MA/London: MIT Press.

Gould, Kenneth A., Allan Schnaiberg, and Adam. S. Weinberg. 1996. Local Environmental Struggles: Citizen Activism in the Treadmill of Production. Cambridge/New York/Melbourne: Cambridge University Press.

Green\$aver. 2001. Website: http://www.gca.ca/GREENSAV.htm

Hannum, Hildegarde. 1997. People, Land, and Community. .New Haven/London: Yale University Press.

Hines, Colin 2000. Localization: A Global Manifesto. London:Earthscan.

Hofrichter, Richard. 2000. Reclaiming the Environmental Debate: The Politics of Health in a Toxic Culture. Cambridge, MA/London: MIT Press.

"Introduction to Bioregionalism". 1991. Working paper presented at the Fourth North American Bioregional Congress, Turtle Island Office.

Korten, David. 1994. "Sustainable Livelihoods: Redefining the Global Social Crisis," International Society for Ecological Economics Newsletter, vol. 5 no. 4, p. 8.

Krugman, Paul. 1997. Pop Internationalism. Cambridge, MA: MIT Press.

Krugman, Paul R. 1990. Rethinking International Trade. Cambridge, MA: MIT Press.

Lang, Tim and Colin Hines. 1993. The New Protectionism: Protecting the Future Against Free Trade. New York: The New Press.

Lappe, Frances (with Paul DuBois). 1994. The Quickening of America: Rebuilding Our 
Nation, Remaking Our Lives. San Francisco: Jossey-Bass.

Leff, Enrique. 1995. Green Production: Toward an Environmental Rationality. New York/London: Guilford Press.

Lipschutz, Ronnie D. 1999. "Bioregionalism, Civil Society, and Global Environmental Governance.” In Michael Vincent McGinnis (ed.), Bioregionalism. London/New York: Routledge.

McMahon, Martha. 2001. "What to Think? Ecofeminism and Eco-Agriculture in Ireland," Women and Environments International, No. 52/53, Fall.

Mellor, Mary. 1993. "Building a New Vision: Feminist, Green Socialism," in Richard Hofrichter, Toxic Struggles: The Theory and Practice of Environmental Justice.

Philadelphia/Gabriola Island, BC: New Society Publishers.

Milani, Brian. 2000. Designing the Green Economy: The Postindustrial Alternative to Corporate Globalization. Lanham, MD: Rowman and Littlefield.

Moggeridge, Donald (ed.).1993. The Collected Writings of John Maynard Keynes. "National Self-Sufficiency", vol. 21. London: Macmillan.

Morrison, Roy. 1995. Ecological Democracy. Boston: South End Press.

Nader, Ralph, et. al. 1993. The Case Against Free Trade: GATT, NAFTA, andthe Globalization of Corporate Power. San Francisco, CA/Berkeley, CA: Earth Island Books.

Nelson, Julie and Marianne Ferber (eds.) 1993. Beyond Economic Man: Feminist Theory and Economics. Chicago/London: University of Chicago Press.

Norberg-Hodge, Helena. 1994. "Building the Case Against Globalization and For Community-Based Economics," International Society for Ecological Economics Newsletter, vol. 5, no. 2, pp. 3-4.

Norgaard, Richard. 1994. Development Betrayed. New York/London: Routledge.

North, Douglass C. 1989. "Institutions and Economic Growth," World Development, 17: 1319_32.

Nozick, Marcia. 1992. No Place Like Home. Ottawa: Canadian Council on Social Development.

Nozick, Marcia. 1999. "Sustainable Development Begins at Home: Community Solutions to Global Problems." In John T. Pierce and Ann Dale (eds.), Communities, Development and Sustainability Across Canada. Vancouver: UBC Press, pp. 3-26. 
O'Connor, Martin (ed.). 1994. Is Capitalism Sustainable? New York/London: Guilford Press.

Palmer, Ingrid. 1992. "Gender Equity and Economic Efficiency in Adjustment Programmes." In Haleh Afshar and Carolyne Dennis (eds.) Women and Adjustment in the Third World. London: Macmillan.

Peet, John. 1992. Energy and the Ecological Economics of Sustainability. Washington/Covelo, CA: Island Press.

Perkins, Ellie. 2000. "Equity, Economic Scale, and the Role of Exchange in a Sustainable Economy". In Fred Gale and Michael M'Gonigle (eds.), Nature, Production, Power: Approaches to Ecological Political Economy. Edward Elgar Publishers, pp. 185-195.

Perkins, Ellie. 1996. "Building Communities to Limit Trade," Alternatives., Vol. 22, No. 1, January/February, pp. 10-15.

Pietila, Hilkka. 1997. "The Triangle of the Human Economy: Household - Cultivation Industrial Production. An Attempt at Making Visible the Human Economy in toto," Ecological Economics, Vol. 20, No. 2, February, pp. 113-128.

Ponting, Clive. 1991. A Green History of the World. New York: Penguin.

Raddon, Mary-Beth. 2002. "Community Currencies, Value and Feminist Politics." Women and Environments International, No. 54/55, Spring, pp. 24-26.

Roberts, Wayne and Susan Brandum. 1995. Get a Life! A Green Cure For Canada's Economic Blues. Toronto: Get A Life Publishing House.

Ropke, Inge. 1993. Trade, Development, and Sustainability: A Critical Assessment of the 'Free Trade Dogma'. Research Paper Series No. 24, Institute of Social Sciences, Technical University of Denmark, Lyngby, Denmark.

Roseland, Mark. 1999. "Natural Capital and Social Capital: Implications for Sustainable Community Development". In John T. Pierce and Ann Dale (eds.), Communities, Development and Sustainability Across Canada. Vancouver: UBC Press, pp. 190-207.

Roseland, Mark (ed.). 1997. Eco-City Dimensions: Healthy Communities, Healthy Planet. Gabriola Island, BC/New Haven, CT: New Society Publishers.

Roseland, Mark. 1998. Toward Sustainable Communities: Resources for Citizens and their Governments. Gabriola Island, BC/Stony Creek, CT: New Society Publishers.

Sachs, Wolfgang. 1993. Global Ecology. Halifax: Fernwood..

Shiva, Vandana. 1993. "The Greening of the Global Reach." In Wolfgang Sachs (ed.), Global Ecology: A New Arena of Political Conflict. Halifax: Fernwood Publishing. 
Shuman, Michael H. 1998. Going Local: Creating Self-Reliant Communities in a Global Age. New York/London/Toronto/Sydney/Singapore: The Free Press.

Sitarz, Daniel (ed.). 1998. Sustainable America: America' Environment, Economy and Society in the $21^{\text {st }}$ Century. Carbondale, IL: Earthpress.

Tobin, James. 1995. The Tobin Tax on International Monetary Transactions. Ottawa: Canadian Centre for Policy Alternatives.

TREC. 2001. Website: http://www.trec.on.ca/about_w.html.

Van der Ryn, Sim and Stuart Cowan. 1996. Ecological Design. Washington, DC/Covelo, CA: Island Press.

Van Staveren, Irene. 2001. The Values of Economics: An Aristotelian Perspective. London/New York: Routledge.

Waring, Marilyn. 1988. If Women Counted. San Francisco: Harper and Row. 